\title{
Untangling Eriotheca gracilipes (Malvaceae, Bombacoideae): A new species and a new combination in Eriotheca
}

\author{
Vania Nobuko Yoshikawa* ${ }^{1 *}$ and Marilia Cristina Duarte ${ }^{1}[0$
}

Received: November 11, 2020

Accepted: April 16, 2021

\begin{abstract}
Eriotheca gracilipes concept is re-circumscribed according to the shape and texture of the leaflets, diameter of the petiole, calyx color, seed striation and geographic distribution. In addition, a new species (Eriotheca uniflora) and a new combination (Eriotheca crenulata) are proposed here. Descriptions, identification key, taxonomic comments, geographic distribution, phenology and conservation status, images of diagnostic characteristics and a table with information about these features are provided for the three species.
\end{abstract}

Keywords: Cerrado biome, endemism, Eriotheca Schott \& Endl., new species, taxonomy

\section{Introduction}

Subfamily Bombacoideae occurs predominantly in the New World and comprises ca. 80 species in 12 genera in Brazil (Bayer \& Kubitzki 2003; Duarte 2010; CarvalhoSobrinho et al. 2016). In cerrado vegetation, about 24 species are estimated (BFG 2020). Small to large trees (2-30 m tall), with unarmed trunks, palmately compound leaves with 1-9 leaflets and fruits with brown, ocher or white kapok characterize the subfamily (Duarte 2010; Duarte et al. 2011; Carvalho-Sobrinho et al. 2014).

Eriotheca belongs to subfamily Bombacoideae and includes treelets or trees (up to $30 \mathrm{~m}$ tall) bearing palmately compound leaves with 3-9 leaflets, small flowers (1.5-5.5 $\mathrm{cm}$ in length) with a constricted staminal tube, and small, obovoid fruits (Duarte 2010). Prior to this publication, the genus comprised ca. 27 species, of which 20 (22 with this publication) are in Brazil and seven occur in cerrado vegetation (Robyns 1963; Carvalho-Sobrinho et al. 2020; Duarte \& Yoshikawa 2020).

The genus is cited in many floristic surveys and taxonomic treatments for Brazil, including a major contribution by Robyns (1963) who segregated 17 species from Bombax s.l. and placed them in Eriotheca. Of these species, Schumann (1886) published 10 species in Bombax. The most recent taxonomic review of Eriotheca was performed by Duarte (2010), who included all Brazilian species known at the time. She provided descriptions and highlighted the diverse morphology of Eriotheca gracilipes.

During a Bombacoideae revision of the Brazilian cerrado including a careful herbaria analysis and field expeditions (Yoshikawa 2019), we realized that Eriotheca gracilipes sensu Robyns (1963) encompasses more than one species in its circumscription. To rectify this, we propose the reestablishment of Bombax crenulatum, synonym of Eriotheca gracilipes for its combination in the genus Eriotheca. Besides, a new species (E. uniflora) is described based on materials from Bahia and Tocantins states. We provide morphological

\footnotetext{
1 Laboratório de Sistemática Vegetal, Núcleo de Ciências Ambientais, Programa de Pós-Graduação em Biotecnologia,

Universidade de Mogi das Cruzes, 08780-911, Mogi das Cruzes, SP, Brazil

* Corresponding author: vania_nobuko@hotmail.com
} 
descriptions, morphological and geographic distribution comments, an identification key and plates for the three species.

\section{Materials and methods}

This study was lead the Laboratório de Sistemática Vegetal (LSV) at the Universidade de Mogi das Cruzes, São Paulo, Brazil. We measured vegetative and reproductive characteristics of specimens using stereomicroscopes, calipers, tweezers and needles. The following herbaria were consulted: CEN, FLAS, HUEFS, HUMC, HUTO, IBGE, MBM, NY, P, PAMG, R, RB, SP, SPF, UEC, UFG, UFMT, UFMS, UB and USZ (acronyms according to Thiers 2020, continuously updated). For Eriotheca crenulata (K. Schum.) Yoshikawa \& M. C. Duarte and Eriotheca gracilipes (K. Schum.) A. Robyns, only the materials that best represent each species were listed. For more information, see the list of exsiccatae (List S1 supplementary material).
We also carried out field expeditions to provide information about features in natura, such as color of the trunk, leaflets, flowers, fruits and seeds, and type of vegetation. The surveys occurred in the states of Mato Grosso, Mato Grosso do Sul and São Paulo, in November 2017, June 2018 and July 2016, respectively.

To characterize Eriotheca gracilipes and contrast it with other species of the genus, we used Schumann (1886), Robyns (1963) and Duarte (2010), and the http://jstor. org/, http://jabot.jbrj.gov.br/ and https://specieslink.net/ websites to analyze type specimens. In addition, we used the International Code of Nomenclature for Algae, Fungi and Plants for nomenclatural issues (Turland et al. 2018).

The distribution map was made with the software Qgis 2.14 (Qgis Development Team 2021), the shapefile from the Ministério do Meio Ambiente (MMA 2020) for the political divisions of the states and Morrone (2017) for biome delimitations. We used the map to help us evaluate the conservation status of the species (IUCN 2017).

\section{Results}

\section{Taxonomic treatment}

\section{Key to Eriotheca gracilipes and similar species}

1. Leaflets, pedicel and calyx pubescent; fruit with angulate locules

\section{Eriotheca estevesiae}

1'. Leaflets, pedicel and calyx lepidote, glabrescent or glabrous, fruit with non-angulate locules 2

2. Leaflets slightly elliptical to oblong; flowers solitary; seeds striate, striations thick (>0.1 cm diam.)

4. Eriotheca uniflora

2'. Leaflets obovate, slightly-obovate to widely obovate (rarely widely elliptical); inflorescence in cymes; seeds striate, striations thin $(<0.1 \mathrm{~cm}$ diam $)$

3. Leaflets widely obovate (rarely widely elliptical), strongly coriaceous, with concolored surfaces; calyx purplish green (in natura)

3. Eriotheca gracilipes

3'. Leaflets obovate to slightly-obovate, chartaceous to slightly coriaceous, with discolored surfaces; calyx evergreen (in natura)

1. Eriotheca crenulata

1. Eriotheca crenulata (K. Schum.) Yoshikawa \& M.C. Duarte comb. nov. Basionym: Bombax crenulatum K. Schum. Fl. Bras. 12(3): 219. 1886. BRAZIL. São Paulo, s.d., Burchell 5252 (lectotype designated by Duarte \& Esteves 2012: K [photo!]), Novon 22(2): 153 (2012). (Figs. 1 and 2).

Shrubs, treelets and trees (1.5)2-8(9-11) m tall, deciduous (rarely evergreen). Trunk $8-100 \mathrm{~cm}$ diam.; branches $0.4-0.8(1.2) \mathrm{cm}$ diam. Leaves palmately compound; petiole (2.5)3.5-9(11-13) cm long, 0.1-0.2 $\mathrm{cm}$ diam., blackish, nectaries 2 , linear; petiolule $0.2-0.7 \mathrm{~cm}$ long, blackish to brownish; leaflets 3-5, 5-10(12-15) × 2.5$7 \mathrm{~cm}$, obovate to slightly obovate, apex emarginate, retuse to emarginate-rounded, base acute to decurrent, margin entire, non-revolute, chartaceous to slightly coriaceous, discolored, adaxial surface greyish (rarely brownish when dry), shiny, abaxial surface brownish, matte, indumentum comprising trichomes and scales (rarely glabrous), trichomes simple, hyaline to blackish, scales with regular outline, brownish to blackish, rounded. Cymes 1-2(3-15), axillary and/or apical, flowers $2.5-3(4) \mathrm{cm}$ diam.; pedicel $0.5-4 \mathrm{~cm}$ long, bracts 1-2, deciduous; flower buds $0.3-0.4(-0.6) \times 0.4$ $\mathrm{cm}$, globoid, ovoid to obovoid, extra-floral nectaries 5 , globose to elliptical, externally on the receptacle; calyx (0.4)0.5-0.8(0.9) × (0.6-0.7)0.8-0.9(1-1.2) cm, cupuliform, 5-10-apiculate, truncate (rarely 5-lobed), dark brownish to blackish when dry (evergreen in natura); petals 5 , $2-3(3.8) \times 0.7-1.5 \mathrm{~cm}$, obovate; staminal tube $0.4-1 \mathrm{~cm}$ long, constricted toward apex; filaments ca. 150, 1-2 cm long, yellowish to purplish red; anthers $0.1-0.2 \mathrm{~cm}$ long, 
yellowish, orange to brownish; style $1-1.5 \mathrm{~cm}$ long, whitish; stigma $0.1 \mathrm{~cm}$ long., 1 -lobed, capitate; ovary $0.3-0.4 \times$ $0.2-0.3 \mathrm{~cm}$, ovoid. Capsules $(2.5-3) 4-8(10) \times 3-6 \mathrm{~cm}$, obovoid. Seeds $0.5-1 \mathrm{~cm}$ long, dark brownish, globoid, glabrous, (3)4-5-striate with thin ( $<0.1 \mathrm{~cm}$ diam.) striations.

Distribution and habitat - Eriotheca crenulata occurs in the Distrito Federal and the states of Goiás, Maranhão, Mato Grosso do Sul, Minas Gerais and São Paulo (Fig. 2), in cerradão, campo cerrado, campo sujo, cerrado sensu stricto, gallery forest and anthropized areas, in sandy, argillaceous and rocky soils, ranging from 120-1080 m in elevation.

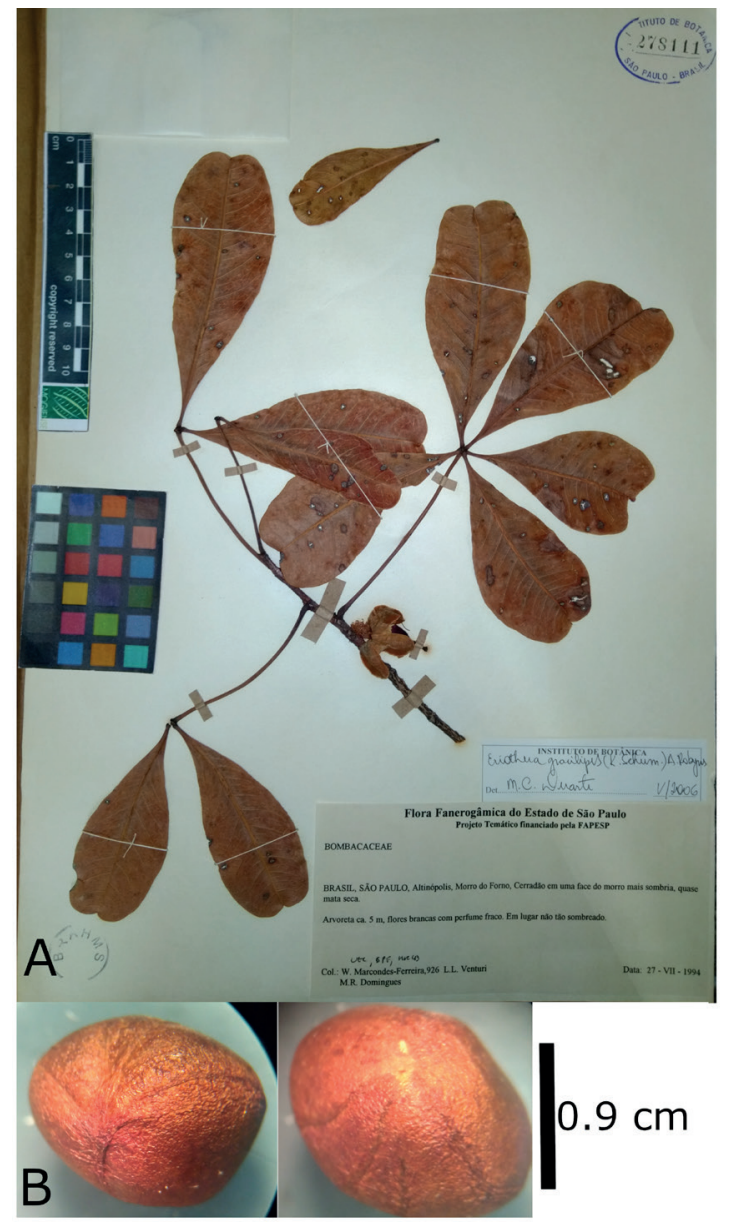

Figure 1. Eriotheca crenulata (K. Schum.) Yoshikawa \& M.C. Duarte. Flowering branch (A) and seed (B).

Common names-Algodoeiro, imbiruçu, paina-docampo, paineira, paineira-do-campo, paineira-do-cerrado.

Phenology-Flowers seen in January, February, April to October and December. Fruits seen in January, May, and July to November.

Conservation status - Least Concern (LC), according to IUCN (2017) criteria. This is a widespread species, with an extent of occurrence of about 1,200,000 $\mathrm{km}^{2}$ and more than 20 distinct localities (Fig. 2).

Comments-Eriotheca crenulata has Bombax crenulatum K. Schum. as basionym, which was synonymized by Robyns
(1963) in E. gracilipes. However, after our analyses, we combined B. crenulatum in E. crenulata because all the analyzed specimens correspond to Schumann's description in Flora Brasiliensis and to the lectotype (Burchell 5252). Bombax crenulatum is combined in Eriotheca due to the morphological characteristics described for the genus (see introduction section).

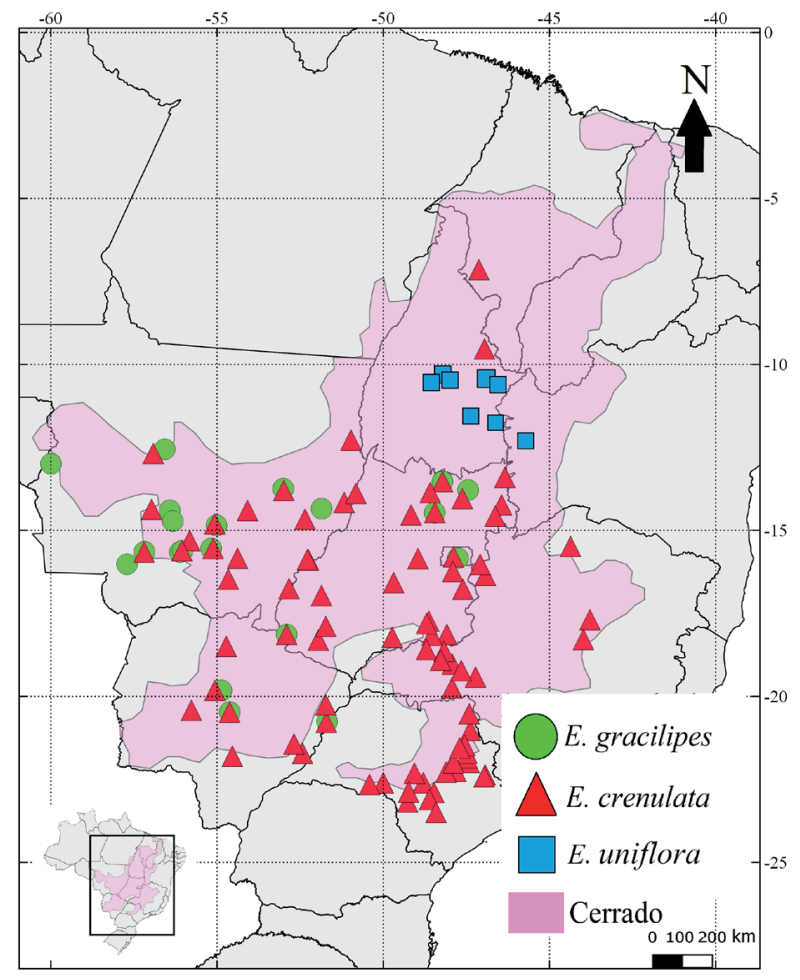

Figure 2. Geographical distribution of the Eriotheca crenulata (K. Schum.) Yoshikawa \& M. C. Duarte, E. gracilipes (K. Schum.) A. Robyns and E. uniflora Yoshikawa \& M. C. Duarte from Brazilian cerrado.

The following comments differentiate this combined name, E. gracilipes, and the new species.

Eriotheca crenulata is morphologically similar to Eriotheca gracilipes and Eriotheca uniflora because it can be a small tree (1-3 m tall) and leaflets with dark areas. However, E. crenulata has slim petiole $(0.1 \mathrm{~cm}$ diam.), slightly obovate, chartaceous to slightly coriaceous leaflets, receptacle with 5 nectaries and a blackish calyx (when dry, evergreen in natura) with a varying apex (5-lobed, apiculate to rarely truncate), while E. gracilipes has thicker petiole (0.3-0.8 $\mathrm{cm}$ diam.) widely obovate, strongly coriaceous leaflets, receptacle with 9 nectaries and a light brownish calyx (when dry, purplish-green in natura) with a truncate apex. Eriotheca uniflora differs from $E$. crenulata by the elliptical, chartaceous to coriaceous leaflets and brownish calyx (when dry) with a truncate apex (Fig. 1 and Tab. 1).

Selected specimens-BRAZIL. Distrito Federal: Brasília, Altiplano leste, 25 October 2015, F. Santos et al. 708 (CEN, UFG). Goiás: Goiandira, Fazenda Chapéu, 24 
Table 1. Morphological differences between Eriotheca crenulata (K. Schum.) Yoshikawa \& M.C. Duarte, Eriotheca gracilipes (K. Schum.) A. Robyns and Eriotheca uniflora Yoshikawa \& M.C. Duarte.

\begin{tabular}{|c|c|c|c|c|}
\hline \multicolumn{2}{|c|}{ Character/Species } & Eriotheca crenulata & Eriotheca gracilipes & Eriotheca uniflora \\
\hline \multicolumn{2}{|c|}{ Branch diameter $(\mathrm{cm})$} & $0.4-0.8(1.2)$ & (0.6)1-2.5 & $0.5-0.6$ \\
\hline \multicolumn{2}{|c|}{ Petiole diameter $(\mathrm{cm})$} & $0.1-0.2$ & $0.3-0.5(-0.8)$ & $0.05-0.1$ \\
\hline \multirow{3}{*}{ Leaflets } & Shape & Obovate to slightly-obovate & $\begin{array}{l}\text { Widely-obovate, rarely widely } \\
\text { elliptical }\end{array}$ & Slightly-elliptical to oblong \\
\hline & Texture & Chartaceous to slightly coriaceous & Strongly coriaceous & Coriaceous \\
\hline & Surfaces & Discolor & Concolor & Discolor, rarely concolor \\
\hline Nectaries (units) & 5 & 9 & 0 & \\
\hline \multirow{2}{*}{ Calyx } & Apex & $\begin{array}{l}\text { 5-10 apiculate, truncate to rarely } \\
\text { 5 lobate }\end{array}$ & $\begin{array}{c}\text { Truncate, rarely inconspicuously } \\
\text { crenulate }\end{array}$ & Truncate \\
\hline & Color & $\begin{array}{c}\text { Dark brownish to blackish } \\
\text { (exsiccatae) evergreen (in natura) }\end{array}$ & $\begin{array}{l}\text { Light-brownish (exsiccatae) } \\
\text { purplish-green (in natura) }\end{array}$ & $\begin{array}{l}\text { Brownish (exsiccatae) } \\
\text { evergreen (in natura) }\end{array}$ \\
\hline \multicolumn{2}{|c|}{ Fruit size $(\mathrm{cm})$} & $(2.5-3) 4-8(10) \times 3-6$ & $6-7.5 \times 2.5-5$ & $4 \times 3-4$ \\
\hline \multicolumn{2}{|c|}{ Seed } & Thin (3) $4-5$ striate & Thin 3-4 striate & Thick 3 striate \\
\hline \multicolumn{2}{|c|}{$\begin{array}{l}\text { Geographical distribution (Brazilian } \\
\text { states and Distrito Federal) }\end{array}$} & $\begin{array}{l}\text { Distrito Federal, Goiás, Mato } \\
\text { Grosso, Mato Grosso do Sul, Minas } \\
\text { Gerais and São Paulo }\end{array}$ & $\begin{array}{l}\text { Distrito Federal, Goiás, Mato } \\
\text { Grosso and Mato Grosso do Sul }\end{array}$ & Bahia and Tocantins \\
\hline
\end{tabular}

September 2005, J.A. Rizzo et al. 13436 (UFG). Maranhão: Carolina, Parque Nacional da Chapada das Mesas, 19 October 2015, A.C. Sevilha et al. 5397 (CEN). Mato Grosso: Rondonópolis, BR-163, 10 June 1988, G. Guarim-Neto et al. 1370 (UFMT). Mato Grosso do Sul: Campo Grande, Três Lagoas, 10 June 1984, E.M. Rotta s.n. (UFMS 265). Minas Gerais: Uberlândia, Parque Municipal Vitório Siquierolli, 15 September 2003, C.C. Oliveira et al. 01 (HUFU). São Paulo: São Paulo, 27 July 1994, W. Marcondes-Ferreira et al. 926 (SP, SPF, UEC).

2. Eriotheca estevesiae Carv.-Sobr. Brittonia 67(1): 30. 2014. Type: BRAZIL. Goiás: Municipio Cavalcante, $13^{\circ} 22^{\prime} 32^{\prime \prime}$ S, 4803'49" W, 19 September 2001, G. PereiraSilva et al. 5392 (holotype HUEFS! isotype CEN!).

Eriotheca estevesiae is a recently described species (Carvalho-Sobrinho et al. 2014). A full description, citation of specimens, illustrations and information on its distribution and ecology can be found in that publication. The species and E. uniflora sp. nov. are sympatric in Tocantins state. To differentiate E. uniflora and E. estevesiae, see the comments under E. uniflora.

3. Eriotheca gracilipes (K. Schum.) A. Robyns. Bull. Jard. Bot. État Bruxelles 33(2): 145. 1963. Type: BRAZIL, Mato Grosso, s.d. Weddell 3336 (lectotype designated by Robyns 1963: P[photo]!). (Figs. 2 and 3).

Shrubs, treelets and trees (1.5)2-6 $\mathrm{m}$ tall, evergreen. Trunk 10-12 cm diam.; branches (0.6)1-2.5 cm diam.
Leaves palmately compound; petiole (6-7.5)9-22(-24) cm long, 0.3-0.5(-0.8) cm diam., blackish to dark brown, nectaries 2, linear; petiolule absent to $0.2-1 \mathrm{~cm}$ long, blackish to dark brown; leaflets 3-5, (9-15)16-24 x (4-4.5)6.5-12.5(-15.5) cm, widely obovate (rarely widely elliptical), apex emarginate-rounded to retuse (rarely mucronate), base acute to decurrent, margin entire, revolute, strongly coriaceous, surfaces concolored, adaxial surface shiny, abaxial surface matte, indumentum comprising trichomes and scales (rarely glabrous), trichomes simple, hyaline to blackish, diminutive, sometimes grouped in a circle, scales with regular outline, black. Cymes 1-10, axillary and/or apical, flowers $3 \mathrm{~cm}$ diam.; pedicel 1-2.5(2.7-4.2) $\mathrm{cm}$ long, bracts 1 (2-3), deciduous; flower buds $0.3-0.8 \times$ $0.3 \mathrm{~cm}$, globoid, ovoid to obovoid, extra-floral nectaries 9 , globoid to ovoid, externally on the receptacle; calyx (0.3-0.4)0.5-0.8 × 0.6-1 cm, campanulate, truncate, light brown (when dry), purplish green (in natura); petals 5, 2-2.7 $\times 1.5 \mathrm{~cm}$, obovate; staminal tube $0.5 \mathrm{~cm}$ long, constricted toward apex; filaments ca. 100-150, 1-2 cm long, yellowish to light purplish red; anthers $0.1-0.2 \mathrm{~cm}$ long, yellowish, purplish red to brownish; style $0.9-1.5 \mathrm{~cm}$ long, whitish; stigma $0.1 \mathrm{~cm}$, 1-lobed, capitate; ovary $0.2-0.4 \times 0.2-0.5$ $\mathrm{cm}$, ovoid. Capsules $6-7.5 \times 2.5-5 \mathrm{~cm}$, obovoid. Seeds $0.7-0.9 \mathrm{~cm}$ long, dark brown, globoid, glabrous, 3-4-striate with thin $(<0.1 \mathrm{~cm})$ striations.

Distribution and habitat-The major known population of Eriotheca gracilipes is in Mato Grosso State, but some small populations also occur in the Distrito Federal 
and the states of Goiás and Mato Grosso do Sul (Fig. 2). This species occurs in cerradão, cerrado sensu stricto, campo cerrado, campo sujo and anthropized areas, in sandy, argillaceous, rocky soils, at 400-1,100 m elevation.

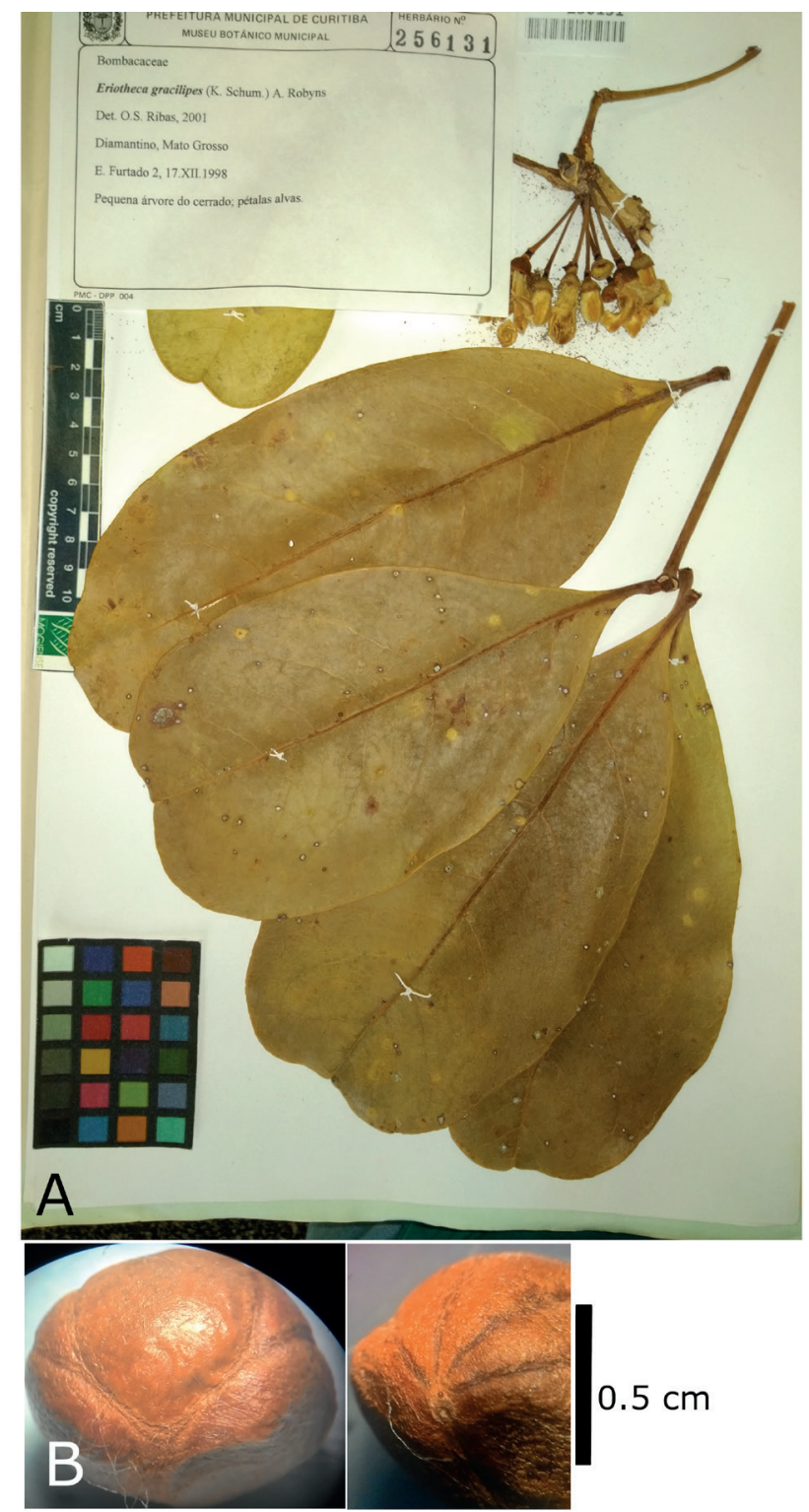

Figure 3. Eriotheca gracilipes (K. Schum.) A. Robyns. Flowering branch (A) and seed (B).

Common names - Embiruçu, paineira, paineira-docampo, paineira-do-cerrado.

Conservation status - Least Concern (LC), according to the IUCN (2017) criteria. This is a widespread species in the cerrado, with an extent of occurrence (EOO) of 434,000 $\mathrm{km}^{2}$ and more than 20 locations (Fig. 2).

Phenology-Flowers seen from May to October and in December. Fruits seen in from August to October.

Comments - The delimitation of E. gracilipes provided by Robyns (1963) comprises specimens distributed predominantly in cerrado with less than $10 \mathrm{~m}$ in height and has 3 - 5 leaflets, being glabrous, lepidote and/or glabrescent (Duarte \& Yoshikawa 2020). During a review of Bombacoideae from the Brazilian cerrado (Yoshikawa 2019), we realized that most of the collections identified as E. gracilipes have dark areas in the leaflets, but the populations from state of Mato Grosso (and some specimens of Goiás and Mato Grosso do Sul states) have morphological differences between samples from the states of Minas Gerais and São Paulo. In addition, the population from the state of Tocantins presented a distinct morphology in the Eriotheca genus, which we treat as a new species (E. uniflora).

As cited above, Eriotheca gracilipes is morphologically similar to Eriotheca crenulata. The characters that differentiate these species are described in the comments under E. crenulata, in Table 1 and identification key.

Selected specimens-Brazil. Distrito Federal: Brasília, Rio São Bartolomeu, 02 August 1987, R.C. Mendonça 850 (IBGE, R, UB). Goiás: Niquelândia, Fazenda Água Clara, 13 August 1996, R.C. Mendonça et al. 2554 (UFG). Mato Grosso: Alto Paraguai, Vão Grande, 21 July 1994, B. Dubs 1556 (E, ESA, K, MBM, S, Z). Mato Grosso do Sul: Corguinho, Fazenda ANB, 15 September 1992, G. Hashimoto 8526 (SP).

4. Eriotheca uniflora Yoshikawa \& M.C. Duarte sp. nov. Type: BRAZIL. Tocantins: Mateiros, Parque Estadual do Jalapão, 08 August 2006, M.L.O. Trovó et al. 304 (holotype SPF! isotype HUEFS!). (Figs. 2 and 4).

Eriotheca uniflora is distinct from other species of the genus by the slightly elliptical to oblong leaflets, solitary flowers and 3-striate seeds with thick striations that emerge at the same point but do not match at the hilum.

Treelets, 1-2 m tall, evergreen. Trunk $24 \mathrm{~cm}$ diam.; branches $0.5-0.6 \mathrm{~cm}$ diam. Leaves palmately compound; petiole (2.5)3-4.5 cm long, $0.05-0.1 \mathrm{~cm}$ diam., nectaries 2, oval-linear, evergreen; petiolule absent, blackish to brownish; leaflets 3(4-5), 4-8.5(-14) × 2-4.5 cm, slightly elliptical to oblong, apex emarginate to rounded, base acute to decurrent, margin entire, non-revolute, coriaceous, discolored (rarely concolored), surfaces matte, glabrescent, indumentum comprising hyaline trichomes and ferruginous, purplish to brownish scales. Cymes 1-flowered, axillary and/ or apical, flower $2.5 \mathrm{~cm}$ diam.; pedicel $1-2 \mathrm{~cm}$ long, with bract scars, bracts $1-2$, deciduous; flower buds $0.6-1 \times$ $0.3-0.5 \mathrm{~cm}$, oblongoid; extra-floral nectaries absent to $1-5$, slightly elliptical, externally on the receptacle; calyx (0.4)0.6-0.7 ×0.7-0.8 cm, campanulate, truncate, brownish (when dry), evergreen (in natura); petals $5,2-2.5 \times 1-2$ $\mathrm{cm}$, obovate; staminal tube $0.5 \mathrm{~cm}$ long, not constricted; filaments ca. $150,0.5-0.7 \mathrm{~cm}$ long, whitish to pinkish; anthers $0.1-0.2 \mathrm{~cm}$ long., yellowish to brownish; style 2-3 $\mathrm{cm}$ long., whitish, stigma $0.1 \mathrm{~cm}$ long, 1-lobed, capitate, ovary $0.2-0.4 \times 0.3-0.5 \mathrm{~cm}$, ovoid. Capsules ca. $4 \times 3-4$ 
$\mathrm{cm}$, obovoid. Seeds $0.5-0.8 \mathrm{~cm}$ long, brownish, globoid, glabrous, 3 -striate with thick ( $>0.1 \mathrm{~cm}$ diam.) striations.

Distribution and habitat-The new species occurs exclusively in cerrado vegetation (cerrado sensu stricto, campo cerrado and campo sujo) in state of Tocantins and some small populations in Bahia (Fig. 2), on rocky, sandy and argillaceous soils, at 200-700 m elevations.

Phenology - Flowers seen from June to August and in October. Fruits seen from August to October.

Conservation status - Vulnerable (VU). According to IUCN (2017) criteria, this species is placed in the vulnerable category for the following reasons: extent of occurrence (EOO) less than $10,000 \mathrm{~km}^{2}$ and less than ten distinct localities (B1a,b [i,iv]) (Fig. 2).

Etymology-The epithet refers to the solitary flowers.

Comments-Many specimens of Eriotheca uniflora are often mistaken from $E$. gracilipes because of its small stature $(1-2 m$ tall) and 3 - 5 leaflets that have frequently dark areas. However, E. uniflora differs from E. gracilipes by its thinner branches ( 0.5 -0.6 vs. [0.6]1-2.5 cm diam), leaflet shape (slightly elliptical to oblong vs. widely obovate) and striate seed (thicker-striate $v$ s. thinner-striate), respectively (Figs. 4B and 3B).

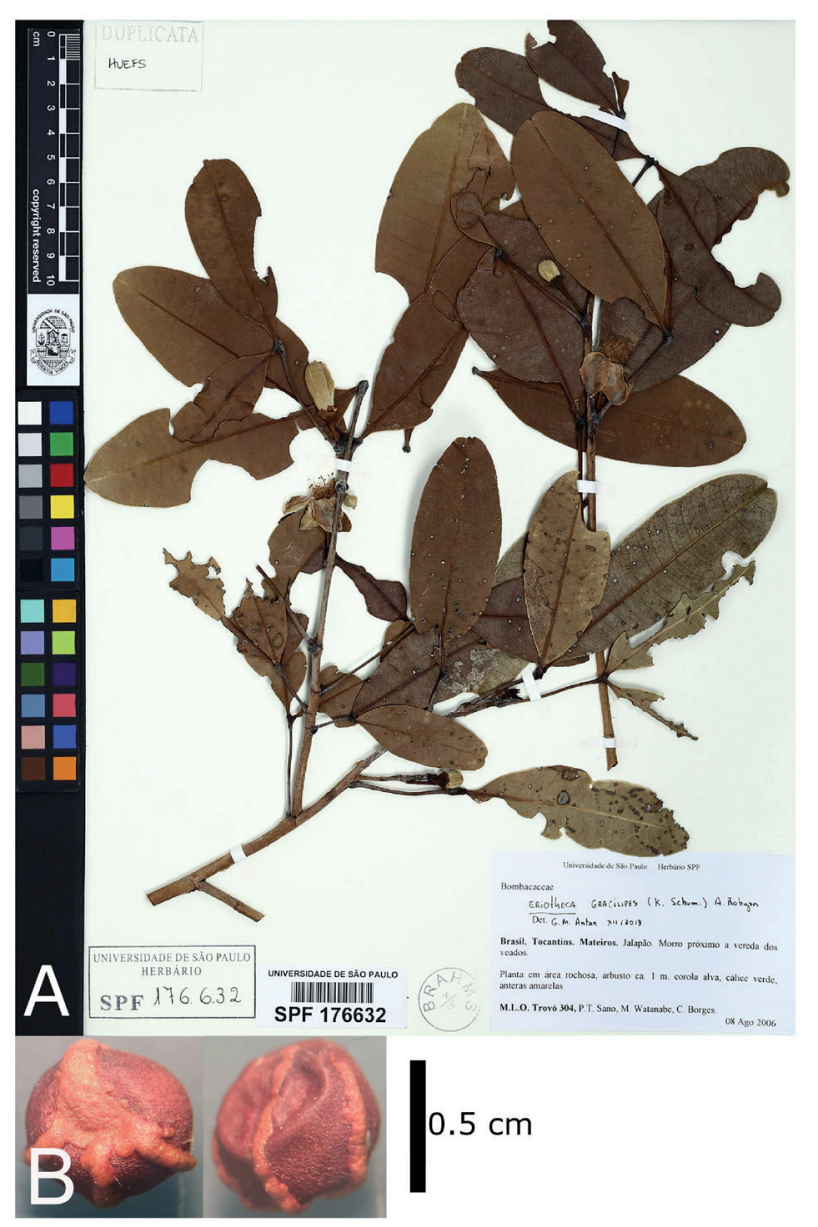

Figure 4. Eriotheca uniflora Yoshikawa \& M.C. Duarte sp. nov. (Holotype). Flowering branch (A) and seed (B). A: available from Herbário Virtual Reflora 2021.
Eriotheca uniflora can also be confused with Eriotheca estevesiae Carv.-Sobr. by the sympatry in the cerrado from the state of Tocantins and by leaflets that are proportionately longer than wide. However, Eriotheca uniflora has leaflets with simple hyaline trichomes, capsules with non-angulate locules and seeds with thick striations (Fig. 4), while Eriotheca estevesiae has yellowish stellate trichomes, capsules with angulate locules and seeds with thin striations.

Additional specimens examined (Paratypes) BRAZIL. Bahia: Barreiras, s.d. A. Cotrim 944 (HUEFS). Tocantins: Almas, Reserva Particular do Patrimônio Natural (RPPN) Fazenda Minnehaha, 10 August 2004, R.C. Mendonça et al. 5674 (IBGE, UEC); ibid., 10 August 2004, B.M.T. Walter et al. 5274 (CEN, IBGE); Dianópolis, 25 September 2003, A.O. Scariot et al. 722 (CEN); Mateiros, Parque Estadual do Jalapão, 31 October 2013, G.M. Antar \& M. Escaramal 304 (CEN, RB, SPF); ibid. 18 June 2002, T.B. Cavalcanti et al. 2938 (CEN); Novo Acordo, estrada Novo Acordo-São Félix do Tocantins, 06 July 2008, E. R. Santos et al. 1673 (HUTO); Palmas, 31 July 2015, R.F. Haidar et al. 1818 (CEN); área urbana, 13 August 2010, R. F. Haidar et al. 1442 (CEN, RB); Canteiro Central da Avenida Teotônio, 15 April 2008, C.R.S. Anjos et al. 15 (HUTO); ibid., 15 April 2008, C.R.S. Anjos et al. 16 (HUTO); Ponta Alta do Tocantins, Fazenda Brejo Grande, 03 October 2011, E. Barbosa et al. 3200 (MBM), Parque Estadual do Jalapão, 06 October 2007, J. Paula-Souza et al. 9013 (SPF); ibid., 08 October 2007, J. Paula-Souza et al. 9236 (SPF).

\section{Discussion}

Schumann (1886) published Bombax crenulatum and B. gracilipes on pages 219 and 221 in Flora Brasiliensis, respectively. He differentiated $B$. crenulatum from $B$. pentaphyllum by its hyaline leaflet margin, smaller flowers and conical ovary that is distinct from the style. Schumann did not differentiate $B$. gracilipes from any other species and characterized this species by its large and glabrous leaflets, thin peduncle and by the truncate (or sometimes inconspicuously crenulated) calyx.

Our work with herbarium specimens was sufficient to differentiate and describe E. uniflora because many were complete with flowers and fruits. Our fieldwork in Bonito (a municipality in the state of Mato Grosso do Sul), Chapada dos Guimarães and Nobres (municipalities in the state of Mato Grosso) and Itirapina (a municipality in the state of São Paulo) confirmed these characteristics and provided others used to differentiate E. crenulata and E. gracilipes.

This work focused on specimens collected in Brazil, as these species predominantly occur in Brazilian territory. However, there are records of $E$. crenulata in Paraguay that have been identified as E. gracilipes (Robyns 1963; GBIF 2021; Species Link 2021; Tropicos 2021), being necessary an update and future analyses of Paraguayan collections. 
Finally, the occurrence of E. crenulata and E. gracilipes is confirmed for Bolivia (GBIF 2021).

\section{Acknowledgements}

We thank the Universidade de Mogi das Cruzes (UMC) for supporting the morphological analyses, to Coordenação de Aperfeiçoamento de Pessoal de Nível Superior (CAPES) for the grants given to the first author (ID 1702566 [20171]), for the reviewers who helped to improve this manuscript and the curators and other employees of the visited herbaria.

\section{References}

Bayer C, Kubitzki K. 2003. Malvaceae. In: Kubitzki K. (ed.) The families and genera of vascular plants. Vol. 5. Berlin, Springer Verlag. p. 225-311.

BFG. 2020. Flora do Brasil 2020/Flora of Brazil 2020. In: Forzza R, Soares AER, Boldorini A, et al. Jardim Botânico do Rio de Janeiro. http:// floradobrasil.jbrj.gov.br/reflora/floradobrasil/FB156. 23 Apr. 2020.

Carvalho-Sobrinho JG, Alverson WS, Alcantara S, Queiroz LP, Mota AC, Baum DA. 2016. Revisiting the phylogeny of Bombacoideae (Malvaceae): Novel relationships, morphologically cohesive clades, and a new tribal classification based on mutilocus phylogeny analysis. Molecular Phylogenetics and Evolution 101: 56-74.

Carvalho-Sobrinho JG, Mota AC, Dorr LJ. 2020. A new species of Eriotheca (Malvaceae, Bombacoideae) from coastal areas in northeastern Brazil. PhytoKeys 167: 31-43.

Carvalho-Sobrinho JG, Mota AC, Queiroz LP. 2014. Eriotheca estevesiae (Malvaceae: Bombacoideae): a new species from the cerrado vegetation of Brazil. Brittonia 67: 29-36.

Duarte MC, Esteves GL, Salatino MLF, Walsh KC, Baum DA. 2011. Phylogenetic Analysis of Eriotheca and Related Genera (Bombacoideae, Malvaceae). Systematic Botany 36: 690-701.
Duarte MC, Yoshikawa VN. 2020. Eriotheca in Flora do Brasil 2020. http:// floradobrasil.jbrj.gov.br/reflora/floradobrasil/FB9049. 21 May 2020.

Duarte MC. 2010. Análise filogenética de Eriotheca Schott \& Endl. e gêneros afins (Bombacoideae, Malvaceae) e estudo taxonômico de Eriotheca no Brasil. São Paulo, Instituto de Botânica da Secretaria de Estado do Meio Ambiente.

GBIF - Global Biodiversity Information Facility. 2021. Eriotheca gracilipes (K.Schum.) A.Robyns. https://www.gbif.org/occurrence/map?taxon key=4073722\&occurrence_status=present. 17 Mar. 2021.

Herbário Virtual Reflora. 2021. Consulta Herbário Virtual: Eriotheca. http:// reflora.jbrj.gov.br/reflora/geral/ExibeFiguraFSIUC/ExibeFiguraFSIUC. do?idFigura=99962491. 29 Mar. 2021.

IUCN. 2017 Guidelines for using the IUCN Red List Categories and Criteria, version 2017.1. Cambridge UK. http://www.iucnredlist. org/documents/RedListGuidelines.pdf. 25 Apr. 2020.

MMA - Ministério do Meio Ambiente. 2020. Biomas. http://www.mma. gov.br/publicacoes/biomas/category/62-cerrado.html. 21 May 2020.

Morrone JJ. 2017. Neotropical biogeography: regionalization and evolution. Vol. I. New York, CRC Press.

Qgis Development Team 2021. Qgis version 3.20.3, 3.16.11 LTR. https:// qgis.org/en/site/. 30 Mar. 2021.

Robyns A. 1963. Essai de Monographie du genre Bombax L. s.l. (Bombacaceae). Bulletin du Jardin Botanique l'État à Bruxelles 33: 1-311.

Schumann K. 1886. Bombacaceae. In: Martius CFP, Eichler AG, Urban I. (eds.) Flora Brasiliensis. Lipsiae, Monachii. p. 201-250.

Species Link. 2021. Eriotheca gracilipes. http://www.splink.org.br/. 26 Jan. 2021.

Thiers B. 2020, continuously updated. Index Herbariorum: A global directory of public herbaria and associated staff. New York Botanical Garden's Virtual Herbarium. http://sweetgum.nybg.org/ih/. 25 Apr. 2020.

Tropicos. 2021. Eriotheca gracilipes. Missouri Botanical Garden. https:// tropicos.org/name/3900478. 26 Jan. 2021.

Turland NJ, Wiersema JH, Barrie FR, et al. 2018. International Code of Nomenclature for algae, fungi, and plants (Shenzhen Code) adopted by the Nineteenth International Botanical Congress Shenzhen, China, July 2017. Glashütten, Koeltz Botanical Books.

Yoshikawa VN. 2019. Estudo taxonômico e biogeográfico de Bombacoideae Burnett (Malvaceae) no Cerrado Brasileiro. MSc Thesis, Universidade de Mogi das Cruzes, Mogi das Cruzes. 